\title{
The Role of Affective Commitment to the Readiness for Changes of E-Puskesmas Entry Officers in Mojokerto District
}

\author{
Farida Wahyu Utami ${ }^{1}$ \\ Ratna Wardani ${ }^{2}$ \\ ${ }^{1}$ UPT Community Health Center \\ of Kedungsari, Mojokerto \\ Regency \\ ${ }^{2}$ IIK STRADA Indonesia
}

Email:

faridawahyutami@gmail.com

Received : March $8^{\text {th }} 2021$

Accepted : April 12 2021

Published : May 20 2021

\begin{abstract}
Every Puskesmas is obliged to organize a Puskesmas Information System. The Puskesmas Information System can be held electronically and / or non-electronically. E-puskesmas is an application developed to fulfill the need for digital data recording at puskesmas. This study aims to analyze the factors of communication and transformational leadership that directly affect and are mediated by the affective commitment factor to readiness. Data collection was conducted through a survey of 172 E-Puskesmas entry officers at 27 Puskesmas in Mojokerto Regency. Statistical test using path analysis. The sampling technique is multistage sampling technique. Statistical results show a positive effect of transformational leadership on affective commitment with a sig value of 0.02 and readiness to change with a sig value of 0.011 . Communication has a positive effect on affective commitment with a sig value of 0.00 and readiness to change with a sig value of 0.00 . Affective commitment has a positive effect on readiness to change dengan nilai sig 0.00 . The limitation in this research is the method of collecting questionnaires with google form so that it allows different perceptions by respondents.
\end{abstract}

Keywords: E-Puskesmas, transformational leadership, communication, affective commitment, readiness, change

Copyright (C) 2021 IIK STRADA Indonesia All right reserved.

This is an open-acces article distributed under the terms of the Creative Commons Attribution-ShareAlike 4.0 International License.

\section{INTRODUCTION}

The Puskesmas Information System is an arrangement that provides information to assist the decisionmaking process in implementing Puskesmas management in achieving its activity objectives. Each Puskesmas is obliged to organize a Puskesmas Information System, which is part of the District / City Health Information System. The Puskesmas Information System can be held electronically and / or non-electronically. To support this, the Health Office has had the E-Puskesmas Application as a recording and reporting application since 2018.

The change in the Puskesmas reporting system from a manual to an electronic system (E-Puskesmas) requires Puskesmas readiness. There are several factors that affect officers' readiness to change, including leadership, communication, and affective commitment. Based on data from the Mojokerto District Health Office on January 1, 2020, out of 27 Puskesmas, there is 1 Puskesmas where 100\% of patients are entered into EPuskesmas, 9 Puskesmas of which $95 \%$ of patients are enrolled at E-Puskesmas, 8 Puskesmas between $80 \%$ to 95\% patients were entered at E-Puskesmas, and 9 Puskesmas where the E-Puskesmas entry was below $80 \%$.

Therefore, this study aims to analyze the communication and transformational leadership factors that directly influence and are mediated by the affective commitment factor to the readiness of E-Puskesmas entry officers at 27 Puskesmas in Mojokerto district in entering patient visits to E-Puskesmas (Wardani et al., 2020). 


\section{MATERIALS AND METHODS}

This research was conducted using a quantitative approach from 2 until 20 November 2020. Based on data collection, the study design used an observational approach that was cross sectional. The population in this study were entry E-Puskesmas officers in 27 Puskesmas in Mojokerto Regency totaling 925 (nine hundred and twenty five) people. The sample of this study were E-Puskesmas entry officers according to the Puskesmas cluster. Sampling is done by multistage sampling, which is a combination of cluster sampling and simple random sampling. Meanwhile, the determination of the sample size uses CS-survey version 2.0. From the results of the formula, if rounded off, the sample size is 172 respondents.

The independent variables in this study are communication and transformational leadership. While the dependent variable are commitment affective and readiness to change. The data scale used in this study is the interval data scale. The data collection process in this study was taken from primary data and secondary data. Primary data by distributing questionnaires and secondary data by interviewing or taking existing data. The validity and reliability of the questionnaire was carried out at Puskesmas as many as 45 questionnaires and data validity testing was carried out using the SPSS software tool using the number (r) from the Corrected Item Total Correlation results through the Scale menu in the Reliability Analysis option. Reliability testing uses Alpha Cronbach measurements. While the test used in this study is the influence test. Tests were carried out with SPSS software tools using non-parametric regression tests. Based on a decision letter from the Health Research Ethics Commission of the Indonesian Strada Institute of Health Sciences number 2219 / KEPK / X / 2020 this research has passed the ethical test

\section{RESULTS}

Data analysts use path analysis, with the following results:

Variabel X1 : Transformational leadership

Variabel X2 : Communication

Variabel Y : Affective Commitment

Table 1.1. Multiple Linear Regression Results between Transformational Leadership and Communication on Affective Commitment

\begin{tabular}{lcccc}
\hline \multicolumn{1}{c}{ Variable } & Sig. Simultan & $\mathbf{R}^{2}$ & Sig parsial & B standardized \\
\hline $\begin{array}{l}\text { Transformational } \\
\text { leadership }\end{array}$ & $.000^{\mathrm{b}}$ & .360 & .020 & .148 \\
Communication & & & & .000 \\
\hline
\end{tabular}

Based on the table above, the value of $\alpha<0.05$, meaning that there is a positive influence between transformational leadership and communication factors on affective commitment. R2 is 0.36 , meaning that transformational leadership and communication have an effect of $36 \%$ on affective commitment.

Variabel X : Affective Commitment

Variabel Y : Readiness to Change

Table 1.2. Multiple Linear Regression Results between Affective Commitment and Readiness to Change

\begin{tabular}{lcccc}
\hline \multicolumn{1}{c}{ Variable } & Sig. Simultan & $\mathbf{R}^{2}$ & Sig parsial & B standardized \\
\hline Affective & $.000^{\mathrm{b}}$ & .271 & .000 & .520 \\
Commitment & & & & \\
\hline
\end{tabular}

Based on the table above, $\alpha<0.05$, meaning that there is a positive influence between affective commitment and readiness to change. The value of $\mathrm{R} 2$ is 0.271 , meaning that affective commitment has an effect of $27 \%$ on readiness to change.

Variabel X1 : Transformational leadership

Variabel X2 : Communication

Variabel Y : Readiness to Change 
Table 1.3. Results of Multiple Linear Regression between Transformational Leadership and Communication on Readiness to Change

\begin{tabular}{lcccc}
\hline \multicolumn{1}{c}{ Variable } & Sig. Simultan & $\mathbf{R}^{2}$ & Sig parsial & B standardized \\
\hline $\begin{array}{l}\text { Transformational } \\
\text { leadership }\end{array}$ & $.000^{\mathrm{b}}$ & .342 & .011 & .164 \\
Communication & & & & \\
\hline
\end{tabular}

Based on the table above, the value of $\alpha<0.05$, meaning that there is a positive influence between transformational leadership and communication on change readiness. The value of R2 is 0.342 , meaning that transformational leadership and communication have an influence of $34 \%$ on readiness to change.

4. Path Analysis Results

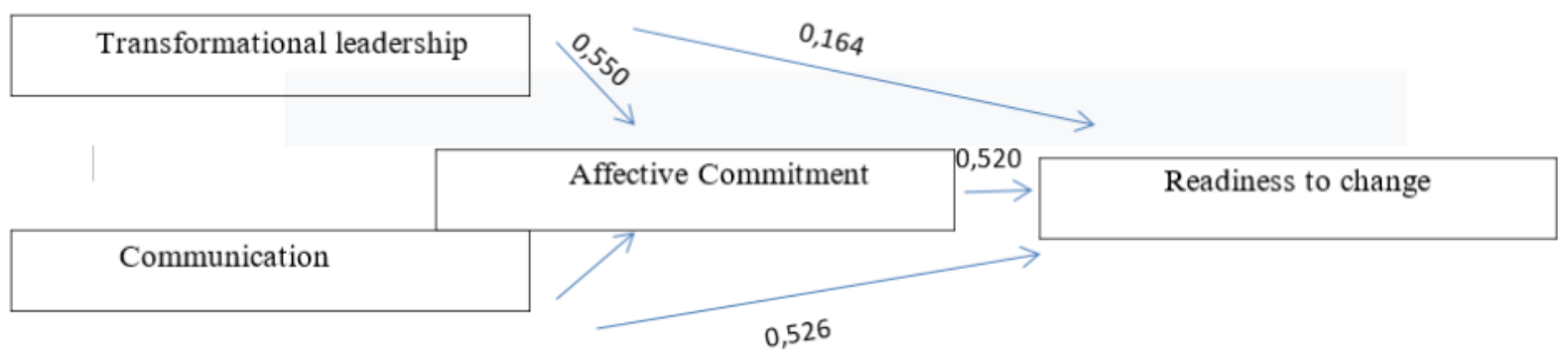

The total effect of the quality of transformational leadership on readiness to change is $0.164+0.550 \mathrm{x}$ $0.520=0.45$. The total effect of communication quality on readiness to change is $0.526+0.148 \mathrm{x}$ $0.520=0.60$.

Table 1.4. Results of Regression Assumptions 1

\begin{tabular}{lc}
\multicolumn{1}{c}{ Table 1.4. Results of Regression Assumptions 1 } \\
\hline Normality test & Sig Value \\
Multicolinearity test (VIF) & 0.200 \\
Leadership variables & \\
Communication variables & 1.053 \\
Heteroscedasticity & 1.053 \\
Leadership variables & \\
Communication variables & 0.997 \\
Linearity & 0.464 \\
Leadership variables & \\
Communication variables & 0.608 \\
\hline
\end{tabular}

Result of Assumption of Regression 2 (Commitment to Readiness)

Table 1.5. Results of Regression Assumptions 2

\begin{tabular}{lc}
\hline \multicolumn{1}{c}{ Assumptions } & Sig Value \\
\hline Normality test & 0.051 \\
Multicolinearity test (VIF) & 1 \\
Heteroscedasticity & 0.368 \\
Linearity & 0.307 \\
\hline
\end{tabular}


Table 1.6. Results of Regression Assumptions 3

\begin{tabular}{lc}
\hline \multicolumn{1}{c}{ Assumptions } & \multicolumn{1}{c}{ Sig Value } \\
\hline Normality test & 0.063 \\
Multicolinearity test (VIF) & \\
Leadership variables & 1.053 \\
Communication variables & 1.053 \\
Heteroscedasticity & \\
Leadership variables & 0.354 \\
Communication variables & 0.204 \\
Linearity & \\
Leadership variables & 0.114 \\
Communication variables & 0.251 \\
\hline
\end{tabular}

Based on the results of the classical assumption test in tables 43,44 , and 45 , the significance value in the normality test is more than 0.05 , so that the data is normally distributed. For the multicollinearity test in tables $43,44,45$ the VIF value is less than 5 , so it can be concluded that there is no multicollinearity between the independent variables. While the results of the heteroscedasticity test in tables 43,44 , and 45 , the significance value for each independent variable is more than 0.05 , so it can be concluded that there is no heteroscedasticity in the data. The last assumption, namely the linearity test in tables 43,44 , and 45 , obtained a value of more than 0.05 , so it can be concluded that the relationship between the two variables $\mathrm{x}$ and the variable $\mathrm{y}$ is a linear relationship.

\section{DISCUSSION}

\section{THE EFFECT OF TRANSFORMATIONAL LEADERSHIP ON AFFECTIVE COMMITMENT}

From the results of statistical analysis, it was obtained that the sig value was 0.02 and the standardized $\beta$ value was 0.148 , which means that there was a positive influence between transformational leadership on affective commitment. This is in accordance with research conducted by Wardani (2020) who conducted a study of 320 health workers involved in implementing the hospital service system, at a hospital in East Java. The results of statistical analysis show that transformational leadership and communication have a positive influence on commitment to change. The results of the path analysis of leadership to commitment are Beta 0.139, t-statistic 2.355, p-values 0.010 .

Transformational leadership is closely related to a commitment to change. The empirical findings highlight the important role of readiness in shaping the link between transformational leadership and commitment. Transformational leadership based on the principles of exchange, transformational and charismatic leadership involves communicating a vision, shifting values, encouraging innovation, and promoting self-efficacy. The idealized influence is that a leader must be a good role model and be followed by subordinates so as to foster respect and trust in him. Intellectual stimulation, namely the leader must be able to stimulate his subordinates to come up with new ideas or opinions and create new innovations under his guidance and direction. Transformational and charismatic leadership styles are more appropriate to changing conditions. Organizations that wish to develop and maintain commitment must pay more attention to the leadership factor.

According to Santhidran (2013) who conducted research on a large well-established energy organization (local, not multinational) in Malaysia with 200 respondents. Leadership was found to influence commitment to change indirectly through readiness for change. It was found that leadership had a significant influence on readiness, and in turn, influenced commitment to change. The statistical results between leadership and commitment are $\beta 0.365$, t-statistic $6.0251 * *, \mathrm{R} 20.133$.

In addition to creating readiness, leaders must also be able to encourage employees to commit to change efforts. Leaders must possess the skills and attributes necessary to engage employees in the transformation process. The leader must be able to enable others to commit to and contribute to the success of the change effort. For this purpose, leaders must possess certain skills and competencies such as integrity, motivation, drive, emotional intelligence, self-confidence, business intelligence and knowledge.

\section{EFFECT OF COMMUNICATION ON AFFECTIVE COMMITMENT}

Communication is the second independent variable that has a positive influence on affective commitment, with a sig value of 0.00 and a standardized $\beta$ value of 0.550 . That is, there is a positive 
influence between communication on affective commitment. This is in accordance with research conducted by Wardani (2020) who conducted a study of 320 health workers involved in the implementation of the hospital service system at a hospital in East Java. Conceptually and empirically, communication is increasingly associated with a commitment to change. Organizational commitment can be increased through definite communication about the wishes and performance of the organization. The results of the path analysis of the relationship between communication and affective commitment are $\beta 0.167$, S.D 0.056 , t-statistic 2.985 , p-value 0.001 .

Interpersonal communication, such as employees' efforts to provide opinions and views regarding the issues around them and communication with superiors, colleagues, and supervisors are factors that affect organizational commitment. Organizations cannot exist if there is no good communication in the organization, employees will not know what they are going to do, managers cannot receive information, and supervisors cannot give orders. Cooperation is not possible because employees do not communicate their needs and feelings. If communication runs effectively it will lead to better work commitment.

\section{THE EFFECT OF AFFECTIVE COMMITMENT ON READINESS TO CHANGE}

In this study, affective commitment has a positive effect on readiness to change, with a sig value of 0.00 and a standardized $\beta$ value of 0.520 . This is in line with research conducted by Kuntz (2013) which took a sample of 102 employees affiliated with changing organizations in New Zealand and Australia. This research on organizational commitment as an antecedent to change reactions is rare, but there is some evidence to suggest that affective commitment may play an important role in the acceptance of organizational change and positive attitudes and reactions to organizational change. Studies to date have shown that employees report greater readiness to change when they feel committed to their organization, although this may depend on the degree to which the change is seen as not imposing drastic transformations of the values and features they identify with. Affective organizational commitment will be positively related to readiness to change (suitability, management support, self-efficacy and personal valence), with $\beta=0.25$ and $\mathrm{p}<0.05$ (Kuntz, 2013).

Affective commitment is positively related to readiness for the change dimension and negatively related to change resistance. Affective commitment to the organization generates positive perceptions of change in valence, although it does not influence other change readiness factors, and is directly related to lower intention to resist change.

\section{THE EFFECT OF TRANSFORMATIONAL LEADERSHIP ON READINESS TO CHANGE}

The transformational leadership variable in this study also has a positive effect on readiness to change with a sig value of 0.011 and a standardized $\beta$ value of 0.164 . This is in line with research conducted by Matthysen (2018) on 340 employees and top management in accounting firms in South Africa. This study used a questionnaire instrument of organizational change-climate change, process and readiness. The quality of change communication, participation, attitudes and leadership support for organizational change is related to the process of how change is handled. Positive relationship between readiness to change and trust in leadership $(r=0.465)$. Belief in leadership shows practical and statistical significance with the sub-constructs of readiness to change.

Trust in the leader during the change process is very important. In organizations where there is belief in top management and change has been implemented successfully in the past, members of the organization are more likely to develop positive attitudes towards change. Leaders need to be more transparent with the implementation of change, so that it is easier for employees to keep up with change when they trust their leader to guide change initiatives.

\section{EFFECT OF COMMUNICATION ON READINESS TO CHANGE}

The results of this study indicate that communication has a positive effect on readiness to change with a sig value of 0.00 and a standardized $\beta$ value of 0.526 . This is in line with Vakola's (2014) research by distributing questionnaires to 183 employees of a technology company that is implementing a large-scale restructuring change project in Greece. Honest, effective and direct communication about change has been shown to reduce resistance to change.

The communication climate represents the degree to which employees believe they receive all necessary information about an issue, such as the organization's vision, strategy, policies, plans, procedures, etc. Emphasis on information about the environment allows recipients of change readiness to change. The communication climate is especially important when an employee is trying 
to identify the pros and cons associated with change. Lack of effective communication will cause an employee's cognitive and affective processes to be negatively affected by change, and as a result, he or she will be less prepared to keep up with change. The $\beta$ value of the influence of communication on readiness to change is 0.08 , Sobel $=2.82$ (Vakola, 2014).

Employees who believe in their abilities and are able to deal with stressful events, such as change, tend to view change as positive, will experience high readiness to change. Assuming management to be trustworthy, confident in management's abilities and having confidence in its intentions, and receiving all the necessary information all influence how employees are pros and cons of change, leading to a higher level of individual readiness to change. Organizations must foster a perception of trust among employees by encouraging open communication, with an emphasis on feedback, accurate information, adequate explanation of decisions, an open exchange of thoughts and ideas.

\section{CONCLUSION}

Based on the results of the research that has been carried out and its discussion, it can be concluded that there is a positive influence between transformational leadership on the affective commitment of Epuskesmas entry officers at 27 Puskesmas in Mojokerto Regency with a sig value of 0.02 and a standardized $\beta$ value of 0.148 . There is a positive influence between communication on affective commitment of the entry officers to the Epuskesmas at 27 Puskesmas in Mojokerto Regency with a sig value of 0.00 and a standardized $\beta$ value of 0.550 . There is a positive influence between affective commitment to readiness to change Epuskesmas entry officers at 27 Puskesmas in Mojokerto Regency with a sig value of 0.00 and a standardized $\beta$ value of 0.520 . There is a positive influence between transformational leadership on the readiness to change Epuskesmas entry officers at 27 Puskesmas in Mojokerto Regency with a sig value of 0.011 and a standardized $\beta$ value of 0.164. There is a positive influence between communication on the readiness to change the entry staff of the Epuskesmas at 27 Puskesmas in Mojokerto Regency with a sig value of 0.00 and a standardized $\beta$ value of 0.526 .

Limitations in this study are, to facilitate the recapitulation process and because they are currently in the Covid19 pandemic, questionnaires are given to respondents using google form. Respondents were not given an understanding of filling out the questionnaire, thus allowing for differences in perceptions between respondents on the questions in the questionnaire.

Suggestions that can be conveyed based on the results of this research are for the Mojokerto District Health Office as the agency in charge of the technical implementation unit of the Puskesmas, which should monitor the evaluation of the implementation of E-Puskesmas at each Puskesmas on a regular basis to maximize the use of E-Puskesmas, give rewards to Puskesmas with E entrian -The best health center. Because the orderliness of E-Puskesmas entry will guarantee the availability of the required reports online.

Suggestions that can be conveyed to PT Telkom as a provider of E-Puskesmas, it is better to make necessary system improvements, integrate with all existing online reporting, considering that there are more and more requests for online reporting from the relevant office.

Suggestions that can be conveyed to BPJS Kesehatan as a partner of PT Telkom in terms of merging applications between P-Care and E-Puskesmas, it is better to immediately finalize the bridging process, so that Puskesmas officers do not work twice for E-Puskesmas and P-Care entries.

Suggestions that can be conveyed to future researchers who use this research as a reference, it is hoped that in the future outputs from E-Puskesmas will be available, so that the effectiveness and efficiency of the E-Puskesmas can be assessed for all interested parties.

\section{ACKNOWLEDGMENTS}

The author would like thank to head and all staff of 27 puskesmas in Mojokerto district, head and staff of the Badan Kesatuan Bangsa dan Politik Mojokerto District, and all parties who have helped the smooth writing of this thesis which cannot be mentioned one by one.

\section{CONFLICTS OF INTEREST}

The author does not have a conflict of interest in this study. 


\section{REFERENCES}

Kuntz, J. R. C. (2013). The Effect of Affective Commitment, Communication and Participation on Resistance to Change: The Role of Change Readiness. 42(1).

Matthysen, M., \& Harris, C. (2003). Relationship between readiness to change and work engagement. SA Journal of Human Resource Management, 16(0), 1-11. https://sajhrm.co.za/index.$\mathrm{php} / \mathrm{sajhrm} /$ article/view/855/1381

Vakola, M. (2014). What's in there for me? Individual readiness to change and the perceived impact of organizational change. Leadership and Organization Development Journal, 35(3), 195209. https://doi.org/10.1108/LODJ-05-2012-0064

Wardani, R., Suhariadi, F., Ratmawati, D., Priyono, S., Suhandiah, S., \& Endah, Y. (2020). How Do Transformational Leadership, Communication and Supply Chain Management Affect Commitment to Change through Readiness for Change ? 9(3), 591-59 